\title{
Optimal planning of hybrid photovoltaic/battery/diesel generator in ship power system
}

\author{
Abba Lawan Bukar ${ }^{1}$, Chee Wei Tan², Kwan Yiew Lau ${ }^{3}$, Ahmed Tijjani Dahiru \\ 1,2,3,4 Division of Electrical Power, School of Electrical Engineering, Universiti Teknologi Malaysia \\ ${ }^{1}$ Department of Electrical Engineering, Faculty of Engineering, Universiti of Maiduguri, Nigeria
}

\begin{abstract}
Article Info
Article history:

Received Jan 5, 2020

Revised Mar 30, 2020

Accepted Apr 16, 2020

Keywords:

Photovoltaic system

Ship power system

$\mathrm{CO} 2$ emission

ABSTRACT

In line with the increasing concern on the pollution release by marine ships, renewable energy technologies in ships power system has received so much attention. Recently, photovoltaic (PV) and energy storage system (ESS) are been integrated into conventional diesel generator in ships power system Nevertheless, improper sizing of the overall ship power station will result in a high investment cost and increase $\mathrm{CO}_{2}$ emission. This paper devised a methodology to compute the optimal size of the ESS, PV and diesel generator in a ship power system to minimize $\mathrm{CO}_{2}$ emission, fuel cost, and investment cost. It is a well-known fact that power generation in a sailing ship depend on the time zone, local time, date, latitude, and longitude along ship navigation route and the condition of the ship power system also differs from power systems on land. The devised method in this paper takes into accounts the geographical and season variation of solar insolation along the route from Lagos (Nigeria) to Conakry (Guinea) and accurately model the power output of PV modules is along the route.
\end{abstract}

This is an open access article under the CC BY-SA license.

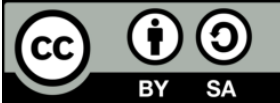

\section{Corresponding Author:}

Chee Wei Tan,

Division of Electrical Power Engineering,

University Teknologi Malaysia,

81310, UTM Skudai, Johor.

Email: cheewei@utm.my

\section{INTRODUCTION}

As the amount of $\mathrm{CO}_{2}$ emission emitted by marine ships increases, the marine industries and international maritime organizations are under pressure from the United Nations and European Union framework convention on climate change to reduce $\mathrm{CO}_{2}$ emissions [1]. Due to the fact that marine ships are powered by conventional DG, the cost of fuel has adversely affected the operational costs of ships. Consequently, efforts are been made to integrate renewable energy (RE) technologies, specifically photovoltaic (PV) and energy storage system (ESS) into the ship power system. The integration of the RE not only mitigates the $\mathrm{CO}_{2}$ emission and fuel cost but also improves power quality, improve energy efficiency. Notwithstanding, the use of RE technologies increases the investment cost and makes the power generated fluctuates from time to time [2,3]. A wide range of research have proven that the used of ESS is one of the most effective methods to improve power quality and reliability of the power system and as well favours the penetration of RE technologies $[4,5]$. Nonetheless, the deployment RE technology may increase the investment cost and make the power system to be wobbly owing to the intermittent behavior of the resources [6]. Some works have confirmed that the optimal management of ESS with RE generators in the ship power system can reduce the cost of operating existing power system and reduce negative environmental impact $[2,7]$. 
A ship power system integrated with a RE system can be viewed as a special mobile and autonomous system. Previous studies have explored hybrid power system arrangements on ships [8-10]. In [9], a DG in conjunction with a lithium-ion battery has been examined for ship crane operation. To minimize fuel consumption, the battery storage system has been used to convert bulk carriers to all-electric ships [11]. Other study have elucidated different control control schemes to reduce fuel consumption and prolong the lifespan of ESS. Also available in the literature are studies related to hybrid PV/Wind/diesel and PV/diesel systems in conjunction with ESS on land for residential purpose [3, 12,13]. Specifically, the optimal sizing of an autonomous PV/Wind/ESS/diesel generator system has been proposed to maximize reliability and minimize the cost of energy [3]. In [14] an optimum unit sizing method has been proposed for a standalone microgrid system. An optimum design for standalone diesel/wind/PV hybrid system under uncertainties of RE sources has been proposed to maximize reliability and the Levelized cost of energy

To the best of our knowledge, hybrid PV/diesel with ESS on ships has not been discussed extensively in the literature [1, 15-18]. Different from the previous works, this study analyses a hybrid PV/diesel with ESS for an oil tanker ship navigating from Lagos in Nigeria to Conakry in Ghana. The shipload variations at full-speed sailing, regular sailing, anchoring, docking, and loading/unloading is been modelled. Finally, a comparison is made based on various system configurations in terms of $\mathrm{CO}_{2}$ emission and cost for the ship power system. The rest of the paper is organized as follows: Section 2 presents the mathematical modelling of the component that composed the hybrid ship power system. Sections 3 present the formulation optimization problem. Section 4 presents the methodology. Section 5 demonstrates exemplary case studies to validate the proposed methodology and finally, the conclusion is drawn out in Section 6.

\section{DESCRIPTION AND MATHEMATICAL MODELLING OF THE HYBRID SHIP POWER POWER SYSTEM}

\subsection{Difference between a ship power system and power system on land}

This study is related to generation planning expansion in ship power system and it differs considerably from autonomous microgrid on land. A ship power system can be viewed as special mobile and autonomous microgrid [1]. The details description of the differences is described in Table 1 .

Table 1. Difference between a ship power system and power system on land

\begin{tabular}{ll}
\hline \multicolumn{1}{c}{ Hybrid ship power system } & Standalone power system on land \\
\hline $\begin{array}{l}\text { Power system is mobile } \\
\text { Irradiance on a sailing ship varies with the time, } \\
\text { date and position of the ship; in addition, it relies on } \\
\text { longitude and latitude. }\end{array}$ & $\begin{array}{l}\text { Power system is fixed in one position. } \\
\text { Fixed irradiance is received. }\end{array}$ \\
$\begin{array}{l}\text { Load varies with the operating modes of the ship } \\
\text { (full-speed sailing, regular sailing, anchoring, } \\
\text { docking and loading/unloading). }\end{array}$ & $\begin{array}{l}\text { Load fluctuates continuously in } \\
\text { standalone power system }\end{array}$ \\
$\begin{array}{l}\text { Loss of power supply probability (LPSP) must be } \\
\text { zero. }\end{array}$ & It is not necessary to guarantee zero LPSP \\
$\begin{array}{l}\text { Sea water crashing on the deck in the ship power } \\
\text { system has a great impact on the efficiency of PV } \\
\text { models. }\end{array}$ & $\begin{array}{l}\text { This phenomenon is not found in the PV } \\
\text { modules on land. } \\
\text { The angle of incidence on the PV array changes due } \\
\text { to fluctuation of the ship }\end{array}$ \\
\end{tabular}

\subsection{Description of the hybrid ship power system and navigation route}

The focus of this study is to optimally design a hybrid power system comprising of PV, ESS, and diesel generator system for an oil tanker ship. Besides, the study further analyzed the emission and cost of the hybrid power system in the oil tanker ship. The work is based on a project named "On the application of RE technology in Oil Tanker Ship" in Sub-Saharan Africa [19]. The detail specifications of the oil tanker ship are that the height, width, and length are $20.6 \mathrm{~m}, 50 \mathrm{~m}$, and $200 \mathrm{~m}$, respectively. The architecture of the hybrid ship power system is shown in Figure 1. The power system consists of diesel generator (DG), PV modules and ESS. The essence of the ESS is to absorb excess power generated by PV and as well improve the reliability of the system. The DG must be able to fulfil the ship energy demand at all time since the ship's power system always operates in standalone mode. The oil tanker ship navigates from Lagos (Nigeria) to Conakry (Guinea) in 5days, and sail on the route five times annually. Precisely, the ship starts sailing at 9:00 am on February $10^{\text {th }}$, April $10^{\text {th }}$, June $10^{\text {th }}$, August $10^{\text {th }}$, October $10^{\text {th }}$ from Lagos and returns February $16^{\text {th }}$, 
April $16^{\text {th }}$, June $16^{\text {th }}$, August $16^{\text {th }}$, October $16^{\text {th }}$ respectively from Conakry. Therefore, the optimization takes into account $1200 \mathrm{~h}$ in a year.

\subsection{Modelling of the ship power system components}

\subsubsection{Photovoltaic system}

During the navigation route from Lagos in Nigeria to Conakry in Guinea, solar irradiance varies with the time, date and position of the ship. The mathematical model to compute for the PV panel power output is defined by (1) $[17,20]$. The model estimates PV power output under varying ambient temperature and solar irradiance.

$$
\operatorname{POW}^{\mathrm{pv}}(\mathrm{t})=\mathrm{P}_{\mathrm{r}}^{\mathrm{pv}} \times\left(\mathrm{G} / \mathrm{G}^{\mathrm{ref}}\right)\left[1+\mathrm{T}^{\mathrm{cof}}\left(\mathrm{T}^{\mathrm{c}}-\mathrm{T}^{\mathrm{ref}}\right)\right]
$$

where $P O W^{p v}$ is the total hourly PV panel output power $(W)$ generated at time $(t), P_{r}^{p v}$ is the PV panel rated power $(W), G$ represent solar irradiance $\left(w / m^{2}\right), G^{\text {ref }}$ represents the solar irradiance at reference conditions having a value of $1000\left(\mathrm{~W} / \mathrm{m}^{2}\right), T^{\text {cof }}$ denote the PV panel coefficient, it is set as $-3.7 \times 10^{-3}\left(1 /{ }^{\circ} \mathrm{C}\right)$ for poly and mono-crystalline silicon [21]. $T^{c}$ denote the PV panel cell temperature, and lastly, $T^{r e f}$ is the PV panel cell temperature at standard test condition, normally set as $25^{\circ} \mathrm{C}$ [22].

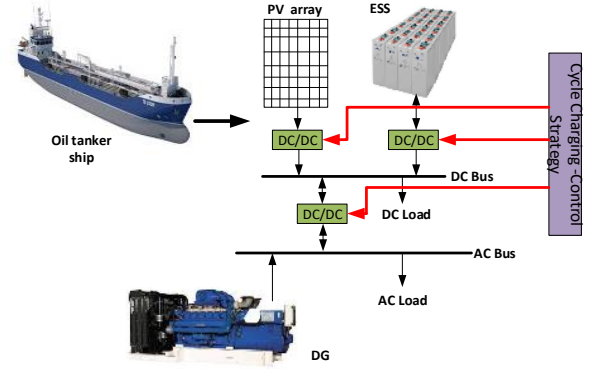

(a)

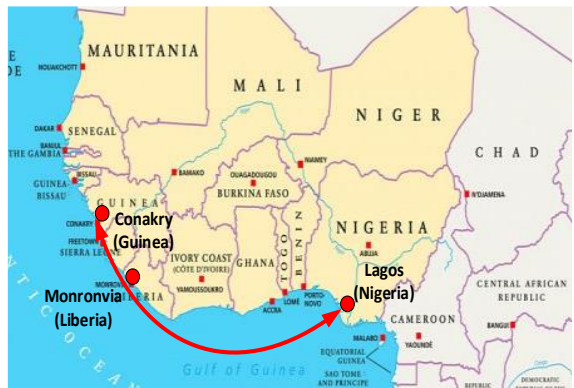

(b)

Figure 1. (a) Hybrid oil tanker ship power system (b) navigation route map

According to the model of PV proposed by Markvar [17, 20], the cell temperature $T^{c}$ can be expressed as follows:

$$
\mathrm{T}^{\mathrm{c}}=\mathrm{T}^{\mathrm{amb}}+\left(\left(\left(\mathrm{T}^{\mathrm{noct}}-20\right) / 800\right) \times \mathrm{G}\right)
$$

where, $T^{a m b}$ represents ambient temperature in ${ }^{\circ} \mathrm{C}, T^{\text {noct }}$ depicts the nominal cell operating temperature in ${ }^{\circ} \mathrm{C}$. It is important to note that the $T^{\text {noct }}$ value depends on the PV module specification and it specified by its manufacturer. Solar irradiance plays an important role in a ship power system. This work, therefore, proposes a modification of the solar irradiance on the ship board. The modification is as follows [23].

$$
\begin{aligned}
& G_{(s, t)}=G_{d(s, t)}+G_{r(s, t)}+G_{b(s, t)} \\
& G_{b, n(s, t)}=\left[\cos (\theta)+\cos ^{2}\left(\frac{\phi}{2}\right) \sin (\chi)+p(\cos \chi+C) \sin ^{2}\left(\frac{\phi}{2}\right)\right]
\end{aligned}
$$

where $G_{d(s, t)}, G_{r(s, t)}, G_{b(s, t)}$ and $G_{b, n(s, t)}$ denote the sky diffuse radiation, ground reflection radiation, direct radiation and direct normal irradiance on a surface which is perpendicular to the sun's rays, respectively. The variables $\chi, C$ and $\rho$ represent the zenith angle, diffuse portion constant and the reflection index, respectively. While $\theta$ represents the angle the solar rays and board and it is computed using 5 [24].

$$
\cos \theta=[\cos \phi \cos \chi+\sin \phi \sin \cos (\xi-C)]
$$

where $\phi$ denote the tilt angle from the horizontal surface and since PV modules are horizontally placed on the shipboard, therefore, $\phi$ is a constant $0 . \quad C$ and $\xi$ denote the plate azimuth and sun azimuth angle, respectively. The azimuth and sun zenith angle can be computed using 6 [25]. 
$\cos \theta=\cos \chi=\sin \lambda \sin \delta+\cos x \cos \lambda \cos \alpha$

where $\lambda$ denote the latitude in degrees, $\delta$ is the solar declination angle which can be computed using 7 and $\alpha$ denote the solar angle, it is determined using (8-13).

$$
\begin{aligned}
& \alpha=23.44 \sin \left[360\left(\frac{\mathrm{d}-80}{365.25}\right)\right] \\
& \beta=\frac{360}{24}(\mathrm{LST}-12) \\
& \mathrm{LST}=\mathrm{LT}+\mathrm{TC} / 60 \\
& \text { TC }=4\left(\mathrm{~L}_{\text {local }}-\mathrm{LSTM}\right)+\mathrm{EOT} \\
& \text { LSTM }=\mathrm{t}_{\text {zone }} \cdot 15^{\circ} \\
& \text { EOT }=9.87 \sin (2 \mathrm{~B})-7.53 \cos (\mathrm{B})-1.5 \sin (\mathrm{B}) \\
& B=360(\mathrm{~d}-81) / 364
\end{aligned}
$$

where $d$ denote the number of days, $L T$ and LST denote the local time and local standard time, respectively. EOT represent the equation of time, taking into account the irregularity of the speed of earth around the sun. $t_{\text {zone }}$ represent the difference between GMT and the current time zone. $L_{\text {local }}$ denote the local longitude. Table 2 presents the specification of the PV that is used in this study [3].

Table 2. Technical and economic parameters of the system components

\begin{tabular}{llll}
\hline \multicolumn{3}{c}{} & \multicolumn{3}{c}{ PV } \\
\hline Rated power & $275 \mathrm{~W}$ & Thickness of PV module & $0.25 \mathrm{~m}$ \\
Initial cost & $\$ 2.15 / \mathrm{W}$ & Efficiency & $17 \%$ \\
$\begin{array}{l}\text { PV regulator cost } \\
\text { Lifetime }\end{array}$ & $\$ 1500$ & Length of PV module & $1 \mathrm{~m}$ \\
Battery & $24 \mathrm{yr}$ & Width of PV module & $0.88 \mathrm{~m}$ \\
$\begin{array}{l}\text { Discharge efficiency } \\
\text { Charging efficiency }\end{array}$ & $100 \mathrm{yr}$ & Lifetime & \\
$\begin{array}{l}\text { Diesel generator } \\
\text { Lifetime }\end{array}$ & $85 \mathrm{yr}$ & Initial cost & $3 \mathrm{yr}$ \\
Rated power & 24,000 hours & Initial cost & $\$ 280 / \mathrm{kW}$ \\
\hline
\end{tabular}

\subsubsection{Battery storage system and energy management strategy}

Due to the sporadic nature of the PV power output, ESS is incorporated to the ship power system to manage the deficit or excess power produced, taking into account the state of charge (SOC) of the ESS. When the power generated by PV modules or the diesel generator exceeds the load demand of the ship, the ESS begins to charge. The charging energy of the battery bank at any given time $t$ can be computed as follows:

$$
E_{E S U(t)}=E_{E S U(t-1)}+\left(E_{P V(t)}+E_{\text {diesel }(t)}-E_{l o a d}(t)\right) \cdot \eta_{c h}
$$

where $E_{l o a d(t)}$ denote the load demand, $E_{E S U(t)}$ and $E_{E S U(t-1)}$ denotes the charging energy of the battery at time $t$ and $t-1, \eta_{c h}$ is the charging efficiency of the battery. Similarly, when the oil tanker ship energy demand exceeds the generated power at time $t$, the ESU discharges to fulfil the ship demand according to (16). Table 2 presents the specification of the battery that is used in this study [3].

$$
E_{E S U(t)}=E_{E S U(t)}-\left(E_{\text {load }(t)}-E_{P V(t)}-E_{\text {diesel }(t)}\right) / \eta_{\text {dis }}
$$

\subsubsection{Diesel generator}

Following the deployment of the PV system to the ship power system, the diesel generator now acts as a backup source. It switched on when the total power generated from PV array and ESU is not sufficient to fulfil the demand of the ship. Consequently, the diesel generator is modelled according to its fuel consumption defined by [3]:

$$
\mathrm{FC}_{\mathrm{d}}=\gamma \cdot \mathrm{P}_{\mathrm{d}}+\delta \cdot \mathrm{P}_{\mathrm{d}}^{\text {rated }}
$$


where $P_{d}$ and $P_{d}^{\text {rated }}$ denote the output and rated power of the diesel generator. $\gamma$ and $\delta$ represent the coefficient of fuel consumption curve and are given as $0.246(\mathrm{~L} / \mathrm{h})$ and $0.0845(\mathrm{~L} / \mathrm{h})$ respectively.

\subsubsection{Load demand}

To achieve a reliable system that would fulfil the load requirement of the ship at all time, all the characteristics of the ship load profile must be considered. The hourly change in the ship load profile with respect to different operating modes of the ship is accounted for in this work. Figure 2a shows the ship load profiles and its different operating modes. The load conditions are $500 \mathrm{~kW}, 1290 \mathrm{~kW}, 1580 \mathrm{~kW}, 1650 \mathrm{~kW}$, and $1790 \mathrm{~kW}$ which correspond to anchoring, unloading/loading, regular cruising, docking, and full-speed sailing, respectively. The plot of the hourly load condition along the route is given in Figure $2 \mathrm{~b}$.

\section{FORMULATION OF THE OPTIMIZATION PROBLEM}

\subsection{Objective functions and constraints}

Based on the system description above, the main objective is to minimize the operating costs and investment of the ships power system and as well the greenhouse emissions from the convention diesel generator system, while satisfying all other operational constraints. Thus, the objective functions are as follows:

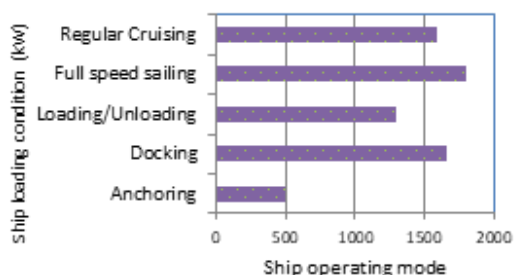

(a)

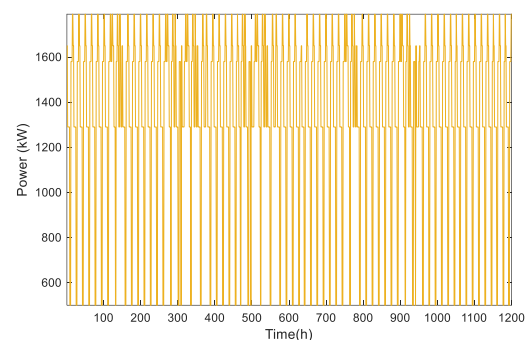

(b)

Figure 2. (a) Ship loading condition (b) Load profile of the ship along the route

$$
\left.\begin{array}{c}
\operatorname{minf}_{1}=\operatorname{Cost}_{p v}+C R F_{p v}+\operatorname{Cost}_{E S S}+\operatorname{Cost}_{\text {fuel }} \\
\operatorname{minf}_{1}=\text { Emission }=\sum_{s=1}^{3} \sum_{t=1}^{240} E_{C O_{x}}\left(P_{G j}\right)=\sum^{3} \sum_{t=1}^{240} \operatorname{Em}_{\text {fuel }} \cdot\left(\gamma \cdot P_{d}+\delta \cdot P_{d}^{\text {rated }}\right)
\end{array}\right\}
$$

The total cost is comprised of installation cost, fuel cost, the replacement cost of PV and ESS. Thus, the costs are defined follows.

$$
\left\{\begin{array}{c}
\text { Cost }_{p v}=\sum_{s=1}^{3} \sum_{t=1}^{3} \text { Price }_{\text {fuel }} \cdot\left(\gamma \cdot P_{d}+\delta \cdot P_{d}^{\text {rated }}\right) \\
\text { Cost }_{E S S}=E S S \cdot\left(C_{\text {replacement }}^{\text {ESS }}+C_{\text {Capital }}^{\text {ESS }}\right) \\
\text { Cost }_{p v}=P_{p v} \cdot\left(C_{\text {replacement }}^{\text {PV }}+C_{\text {Capital }}^{\text {PV }}\right)
\end{array}\right.
$$

where $C_{\text {replacement }}^{E S S}, C_{\text {Capital }}^{E S S}, C_{\text {Capital }}^{P V}, C_{\text {replacement }}^{\text {PV }}$ denotes the replacement and installation cost for

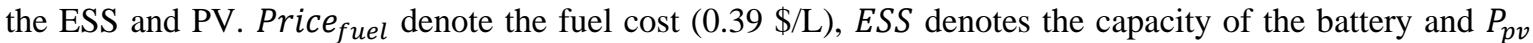
denote the size o the PV $(\mathrm{kW})$. To convert the initial system capital cost to annual capital, (19) for capital recovery factor $(\mathrm{CRF})$ is applied for the purpose.

$$
C R F=\frac{r(1+r)^{x}}{(1+r)^{x}-1}
$$

where $r$ denote the real interest rate and $x$ is the life span of the ESS and PV. For the hybrid ship power station, the following operational constraints must be fulfilled.

$$
\left.\begin{array}{c}
E_{E S S} \leq E_{E S S} \leq E_{E S S} \\
P_{\text {diesel }(\min )} \leq P_{\text {diesel }} \leq P_{\text {diesel (max })} \\
P_{p v} \leq P_{p v} \leq P_{p v(\max )}
\end{array}\right\}
$$


And most importantly, the active power should be balanced in such a way that,

$P_{p v}+P_{E S S}+P_{\text {diesel }}=P_{\text {Load }}$

where $E_{E S S}, P_{p v}, P_{\text {diesel }}$ denote the output of ESS, PV and diesel generator respectively, considering the time $(\mathrm{t})$ and seasonal variation $(\mathrm{s}) . P_{\text {Load }}$ represent the ship load demand.

\section{METHODOLOGY}

Since the formulation of the sizing design problem is formulated as a constrained nonlinear optimization problem, particle swarm optimization is used to solve the optimization problem in this paper. PSO was first developed by Kennedy and Eberhart in 1995 [2][7]. The basic concept involves in the PSO is the random generation of swarm of particles also known as the population of individuals. Each particle in the swarm is representing a potential solution to the optimization problem flies via an $n$-dimensional search landscape at a random velocity. The position of each swarm is updated based on its best global experience, its best exploration, and its previous velocity vector, using the following formulae. Figure 3 presents the flowchart of the proposed methodology.

$$
\begin{aligned}
& \mathrm{x}_{\mathrm{i}}^{\mathrm{k}+1}=\mathrm{x}_{\mathrm{i}}^{\mathrm{k}}+\mathrm{v}_{\mathrm{i}}^{\mathrm{k}+1} \\
& v_{i}^{k+1}=w v_{i}^{k}+c_{1} r_{1}\left(\text { pbest }_{k}^{i}-x_{k}^{i}\right)+c_{2} r_{2}\left(\text { gbest }_{k}^{i}-x_{i}^{k}\right)
\end{aligned}
$$

Where $w$ denote the inertia weight, $r_{1}$ and $r_{2}$ denote random number between 0 and $1, c_{1}$ and $c_{2}$ denote acceleration constant, $p_{\text {best }}$ denote the best historic position attain by particle $i$.

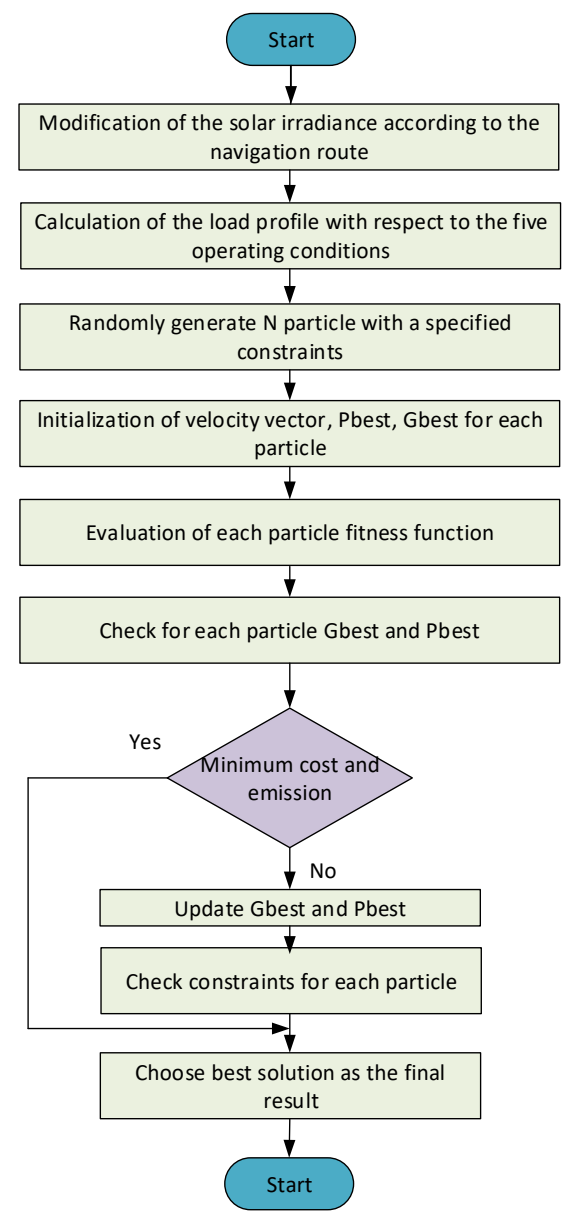

Figure 3. Flowchart of the proposed methodology 


\section{SIMULATION RESULTS AND DISCUSSION}

Bearing in mind the influence of solar radiation on the optimal sizing design problem, the correction coefficient $\cos (\theta)$ of the PV modules is investigated in this paper and taking into account the parameters of (4)-(12). In this regard, the solar irradiation is sampled along the route from Lagos in Nigeria to Conakry in Guinea. Thus, the solar irradiance obtained for the PV system on the ship board is given in Figure 4a. To strengthen the study, an economic analysis on the impact of integrating PV and ESS into the ship power system considering different loading condition is analyzed to demonstrate the effectiveness of the proposed PSO method. For comparison purpose, three cases are considered:

Case 1: The cost considering the ship power system with diesel generator only.

Case 2: The cost of ship power system with PV and diesel generator only.

Case 3: The cost ship power system considering ESS, PV and diesel generator.

Table 3 present the $\mathrm{CO}_{2}$ that would be emitted and the total cost of the ship power system for Case 1, Case 2, and Case 3. It can be seen in Table 3, the output of the DG power is reduced with the deployment of PV in both Case 2 and Case 3. The emission is also reduced in since the diesel generator operation is compensated with PV and ESS. In case 1, the ship energy demand is continuously supplied by DG. Therefore, it results in high cost and the problem of $\mathrm{CO}_{2}$ emission is much higher. In case 2, even though the PV is installed into the system, the system configuration has the highest cost of about $(\$ 1,216,300)$, this implies that ESS is essential in the power system and optimization process must be performed. Outstandingly, when ESS is incorporated the fuel cost and system cost drastically reduce to $\$ 522,905$ and $\$ 1,003,600$ respectively. A fuel price of $0.39 \$ / \mathrm{L}$ is used for the estimation. Figure $4 \mathrm{~b}$ depicts the summary of the comparison for the three different scenarios.

Table 3. $\mathrm{CO}_{2}$ emission and net present cost for four different system configurations

\begin{tabular}{llll}
\hline & Case 1 & Case 2 & Case3 \\
\hline Size of PV (kW) & 0 & 8,280 & 5,346 \\
Capacity of ESS (kW h) & 0 & 0 & 7,400 \\
NPC $(\$)$ & $1,056,645$ & $1,216,300$ & $1,003,600$ \\
PV installation cost & 0 & 13,670 & 10,867 \\
ESS installation cost & 0 & 0 & 677 \\
PV replacement cost & 0 & 13,670 & 10,400 \\
ESS replacement cost & 0 & 0 & 16,767 \\
Fuel Cost (\$) & 967,678 & 820,600 & 522,905 \\
Emission (kg) & $19,323,122$ & $8,560,730$ & $2,750,400$ \\
Total diesel output $(\mathrm{kW}$ & $5,286,176$ & $4,906,443$ & $3,050,200$ \\
\hline
\end{tabular}

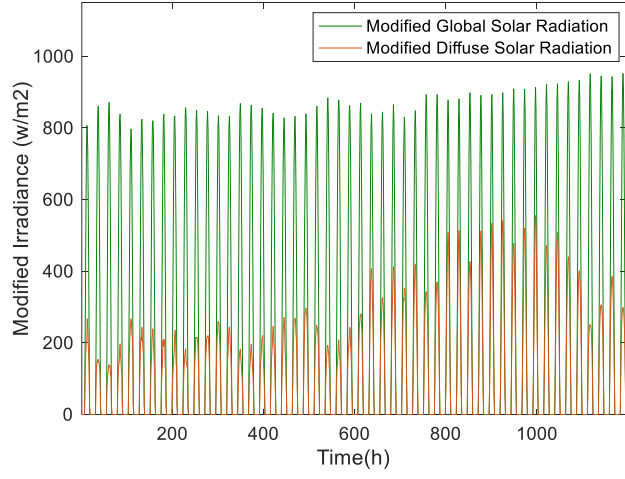

(a)

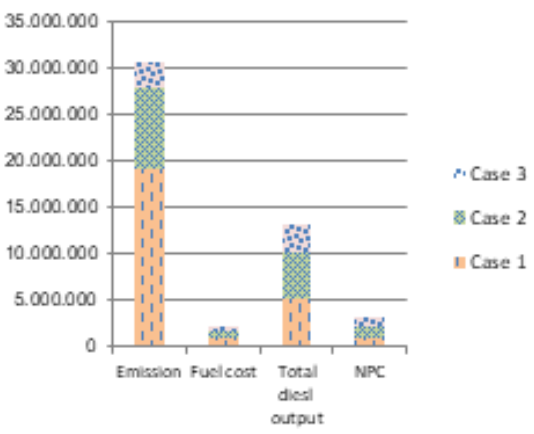

(b)

Figure 4. (a) Modified solar irradiance along the route (b) Comparison of the $\mathrm{CO}_{2}$ emission and NPC for the three scenerios

\section{CONCLUSION}

A methodology to compute for the optimum size of hybrid PV/ESS/DG in a ship power system has been presented in this paper. Hourly loads profile of the ship is modelled with respect to the ship five operating conditions namely, anchoring, unloading/loading, regular cruising, docking, and full-speed sailing. Navigation route from Lagos in Nigeria to Conakry in Guinea is considered as a case study. Followed by the application of PSO to compute for the best size of ESS and PV, and to optimize diesel generator output so as

Optimal planning of hybrid photovoltaic/battery/diesel generator in ship power ... (Abba Lawan Bukar) 
to reduce emission and total cost. The simulation result obtained shows that the net present cost of the ship power system that constitutes PV/ESS/diesel generator is less than that of the ship power system that constitutes PV/diesel generator. Some of the findings attained are as follows: (i) the time zone and as well the local time has a great influence on the correction coefficient for PV power in the ship power system. (ii) Solar irradiance greatly affects the PV power generation during summer than in any other season. The proposed methodology can be improved and applied to other microgrids that are mobile, such as a high-speed train and container ship.

\section{REFERENCES}

[1] S. Wen, H. Lan, D. C. Yu, Q. Fu, Y.-Y. Hong, L. Yu, et al., "Optimal sizing of hybrid energy storage sub-systems in PV/diesel ship power system using frequency analysis," Energy, vol. 140, pp. 198-208, 2017.

[2] A. L. Bukar and C. W. Tan, "A review on stand-alone photovoltaic-wind energy system with fuel cell: System optimization and energy management strategy," Journal of cleaner production, 2019.

[3] A. L. Bukar, C. W. Tan, and K. Y. Lau, "Optimal sizing of an autonomous photovoltaic/wind/battery/diesel generator microgrid using grasshopper optimization algorithm," Solar Energy, vol. 188, pp. 685-696, 2019.

[4] M. S. Ngan and C. W. Tan, "Assessment of economic viability for PV/wind/diesel hybrid energy system in southern Peninsular Malaysia," Renewable and Sustainable Energy Reviews, vol. 16, pp. 634-647, 2012.

[5] A. L. Bukar, C. W. Tan, K. Y. Lau, and A. Marwanto, "Economic Analysis of Residential Grid-connected Photovoltaic System with Lithium-ion Battery Storage," in 2019 IEEE Conference on Energy Conversion (CENCON), 2019, pp. 153-158.

[6] N. M. Isa, A. L. Bukar, T. C. Wei, and A. Marwanto, "Optimal Sizing of Hybrid Fuel Cell and PV Employing Hybrid PSO-GA," in 2019 IEEE Conference on Energy Conversion (CENCON), 2019, pp. 159-164.

[7] M. I. Hlal, V. K. Ramachandaramurthya, S. Padmanaban, H. R. Kaboli, A. Pouryekta, T. Abdullah, et al., "NSGAII and MOPSO based optimization for sizing of hybrid PV/wind/battery energy storage system," Int. J. Power Electron. Drive Syst, vol. 10, pp. 463-478, 2019.

[8] C. Yan, G. K. Venayagamoorthy, and K. A. Corzine, "Optimal location and sizing of energy storage modules for a smart electric ship power system," in 2011 IEEE Symposium on Computational Intelligence Applications In Smart Grid (CIASG), 2011, pp. 1-8.

[9] E. Ovrum and T. Bergh, "Modelling lithium-ion battery hybrid ship crane operation," Applied Energy, vol. 152, pp. $162-172,2015$.

[10] B. Zahedi, L. E. Norum, and K. B. Ludvigsen, "Optimized efficiency of all-electric ships by dc hybrid power systems," Journal of power sources, vol. 255, pp. 341-354, 2014.

[11] E. K. Dedes, D. A. Hudson, and S. R. Turnock, "Assessing the potential of hybrid energy technology to reduce exhaust emissions from global shipping," Energy policy, vol. 40, pp. 204-218, 2012.

[12] A. L. Bukar, B. Modu, Z. M. Gwoma, M. Mustapha, A. B. Buji, M. B. Lawan, et al., "Economic Assessment of a PV/Diesel/Battery Hybrid Energy System for a Non-Electrified Remote Village in Nigeria," European Journal of Engineering Research and Science, vol. 2, pp. 21-31, 2017.

[13] A. Maleki and A. Askarzadeh, "Artificial bee swarm optimization for optimum sizing of a stand-alone PV/WT/FC hybrid system considering LPSP concept," Solar Energy, vol. 107, pp. 227-235, 2014

[14] B. Zhao, X. Zhang, P. Li, K. Wang, M. Xue, and C. Wang, "Optimal sizing, operating strategy and operational experience of a stand-alone microgrid on Dongfushan Island," Applied Energy, vol. 113, pp. 1656-1666, 2014.

[15] K.-J. Lee, D.-S. Shin, J.-P. Lee, D.-W. Yoo, H.-K. Choi, and H.-J. Kim, "Hybrid photovoltaic/diesel green ship operating in standalone and grid-connected mode in South Korea-Experimental investigation," in 2012 IEEE Vehicle Power and Propulsion Conference, 2012, pp. 580-583.

[16] F. Adamo, G. Andria, G. Cavone, C. De Capua, A. M. L. Lanzolla, R. Morello, et al., "Estimation of ship emissions in the port of Taranto," Measurement, vol. 47, pp. 982-988, 2014.

[17] H. Lan, S. Wen, Y.-Y. Hong, C. Y. David, and L. Zhang, "Optimal sizing of hybrid PV/diesel/battery in ship power system," Applied energy, vol. 158, pp. 26-34, 2015.

[18] S. Wen, H. Lan, Y.-Y. Hong, C. Y. David, L. Zhang, and P. Cheng, "Allocation of ESS by interval optimization method considering impact of ship swinging on hybrid PV/diesel ship power system," Applied Energy, vol. 175, pp. 158-167, 2016.

[19] A. Dolatabadi and B. Mohammadi-Ivatloo, "Stochastic risk-constrained optimal sizing for hybrid power system of merchant marine vessels," IEEE Transactions on Industrial Informatics, vol. 14, pp. 5509-5517, 2018.

[20] M. H. Amrollahi and S. M. T. Bathaee, "Techno-economic optimization of hybrid photovoltaic/wind generation together with energy storage system in a stand-alone micro-grid subjected to demand response," Applied Energy, vol. 202, pp. 66-77, 2017.

[21] A. Maleki and F. Pourfayaz, "Optimal sizing of autonomous hybrid photovoltaic/wind/battery power system with LPSP technology by using evolutionary algorithms," Solar Energy, vol. 115, pp. 471-483, 2015.

[22] A. Hiendro, Y. Ismail, F. T. P. Wigyarianto, K. H. Khwee, and J. Junaidi, "Optimum Renewable Fraction for Gridconnected Photovoltaic in Office Building Energy Systems in Indonesia," International Journal of Power Electronics and Drive Systems, vol. 9, p. 1866, 2018.

[23] H. Lan, J. Dai, S. Wen, Y.-Y. Hong, D. C. Yu, and Y. Bai, "Optimal tilt angle of photovoltaic arrays and economic allocation of energy storage system on large oil tanker ship," Energies, vol. 8, pp. 11515-11530, 2015. 
[24] H. Lan, Y. Bai, S. Wen, D. C. Yu, Y.-Y. Hong, J. Dai, et al., "Modeling and stability analysis of hybrid pv/diesel/ess in ship power system," Inventions, vol. 1, p. 5, 2016.

[25] A. Anvari-Moghaddam, T. Dragicevic, L. Meng, B. Sun, and J. M. Guerrero, "Optimal planning and operation management of a ship electrical power system with energy storage system," in IECON 2016-42nd Annual Conference of the IEEE Industrial Electronics Society, 2016, pp. 2095-2099.

\section{BIOGRAPHIES OF AUTHORS}

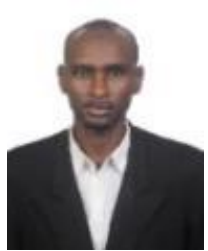

Abba Lawan Bukar is undergoing a PhD degree in Electrical Engineering at Universiti Teknologi Malaysia, Johor, Malaysia. His research interests include renewable/alternative energy systems and energy management.

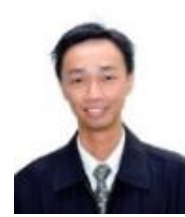

Chee Wei Tan is an Associate Professor at Universiti Teknologi Malaysia and a member of the Department of Electrical Power, Faculty of electrical engineering. His research interests include the application of power electronics in renewable/alternative energy systems.

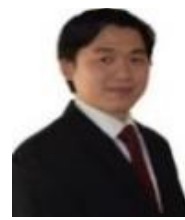

Kwan Yiew Lau is a Senior Lecturer at the Institute of High Voltage and High Current, Universiti Teknologi Malaysia.

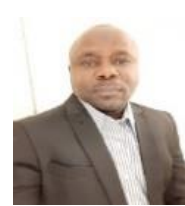

Ahmed Tijjani Dahiru is currently undergoing a $\mathrm{PhD}$ in Electrical Engineering Programme at Universiti Teknologi Malaysia, Johor, Malaysia. His research interests include renewable energy integration into power distribution networks. 